\title{
Sifat Optik Carbon Dots (C-Dots) dari Daun Bambu Hasil Sintesis Hijau Berbantukan Gelombang Mikro
}

\author{
Permono Adi Putro ${ }^{1}$ *, Akhiruddin Maddu ${ }^{2}$ \\ ${ }^{1}$ Program Studi Pendidikan Fisika, Universitas Muhammadiyah Prof. Dr. Hamka, \\ Jl. Tanah Merdeka 20 Jakarta 13830, Indonesia \\ ${ }^{2}$ Departemen Fisika, Institut Pertanian Bogor, Jl. Meranti Wing S Level 5 Bogor \\ 16680, Indonesia
}

*Penulis Penanggungjawab.E-mail : permonoadi29@gmail.com $H P:+6281260633316$

\begin{abstract}
ABSTRAK
Carbon dots (C-dots) adalah tipe baru dari nanopartikel berpendar yang dapat mudah disintesis dari sumber alami. Sintesis C-dots dari daun bambu telah berhasil dilakukan menggunakan teknik sintesis hijau berbantukan gelombang mikro. Teknik sintesis hijau dilakukan dengan menggunakan air sebagai pelarut non-kimia dan sumber alami. Sintesis dilakukan menggunakan variasi konsentrasi prekursor untuk dipelajari pengaruhnya terhadap sifat fisik dan sifat optiknya. Sifat fisik C-dots menunjukkan warna transparan di bawah cahaya tampak, dan warna hijau di bawah laser UV $405 \mathrm{~nm}$. Sifat optik C-dots dikarakterisasi menggunakan spektrofotometer UV-Vis, dan spektrofotometer dengan sumber eksitasi $405 \mathrm{~nm}$. Konsentrasi prekursor mempengaruhi intensitas eksitasi dan emisi, namun pergeseran Stokes C-dots memiliki kestabilan yang sangat baik dalam larutan berair. Pergeseran Stokes berasal dari keadaan transisi $n-\pi^{*}$ dari struktur ikatan aromatik $\mathrm{C}=\mathrm{O}$ pada permukaan $\mathrm{C}$-dots. Kami peroleh $\mathrm{C}$-dots yang berpotensi untuk diaplikasikan sebagai bioimaging seluler in vivo dan in vitro dan biosensing ion logam dan garam.
\end{abstract}

Kata Kunci : C-dots; konsentrasi prekursor; sifat optik; sintesis hijau; gelombang mikro 


\begin{abstract}
Carbon dots (C-dots) are a new type of fluorescent nanoparticles that can be easily synthesized from natural resources. The synthesis of C-dots from bamboo leaves was successfully carried out using microwave assisted green synthesis techniques. Green synthesis techniques are carried out using water as a non-chemical solvent and natural sources. Synthesis is carried out using variations in the concentration of precursors to be studied for their effects on the physical and optical properties. The physical properties of C-dots show transparent colors under visible light, and green color under the UV $405 \mathrm{~nm}$ laser. The optical properties of C-dots were characterized using a UV-Vis spectrophotometer, and a Fluorescence spectrophotometer with an excitation source of $405 \mathrm{~nm}$. Precursor concentrations affect excitation and emission intensity, but Stokes's shift to C-dots has excellent stability in aqueous solutions. Stokes' shift originated from the transition state $n-\pi^{*}$ from structure of aromatic bond $\mathrm{C}=\mathrm{O}$ on surface of $\mathrm{C}$-dots. We obtained $\mathrm{C}$-dots which have the potential to be applied as cellular bioimaging in vivo and in vitro and biosensing metal ions and salts.
\end{abstract}

Keywords: C-dots; precursor concentration; optical properties; green synthesis; microwave

\section{Pendahuluan}

Carbon dots (C-dots) adalah kelas baru nanopartikel fluoresensi berbasis inti karbon. C-dots memiliki stabilitas yang tinggi yang tahan lama, ketahanan (resistansi) yang luar biasa terhadap cahaya (foto) dan degradasi kimia, emisi dan eksitasi fluoresensi yang tunable, high quantum yield, pergeseran Stokes yang besar, dapat larut dalam air karena proses sintesisnya dilakukan dalam air [1]. C-dots memiliki diameter di bawah 10 nm. C-dots yang lebih kecil dari radius Bohr dapat luminesensi ketika quantum confinement effect mendominasi. Distribusi ukuran C-dots yang heterogen terkonjugasi $\mathrm{sp}^{2}$ dalam matrik $\mathrm{sp}^{3}$ non-konjugasi sehingga menghasilkan tingkat energi diskrit yang mengarah pada sifat optik, listrik, dan kimia yang sangat berbeda dibandingkan dengan nanopartikel lainnya [2].

C-dots dapat disintesis menggunakan dua metode yang berbeda; pendekatan top down dan bottom up biasanya terdiri dari unsur-unsur seperti karbon, hidrogen, dan oksigen. Atom-atom lain seperti nitrogen, boron, sulfur, dll. dapat dimasukkan melalui metode doping yang sesuai 
sehingga mengubah sifat-sifatnya [3]. Sintesis nanopartikel dengan cara memecah partikel berukuran besar menjadi partikel berukuran nanometer disebut metode top-down. Metode top -down diantaranya terdiri dari metode arc discharge, laser ablation, electrochemical oxidation, chemical oxidation, dan ultrasonic synthesis. Metode bottom-up menggunakan atomatom atau molekul-molekul yang membentuk partikel berukuran nanometer yang dikehendaki, seperti microwave synthesis, thermal decomposition, hydrothermal treatment, templated routes, dan plasma treatment [4-8].

Teknik gelombang mikro adalah sebuah pendekatan bottom-up untuk mensintesis C-dots secara sederhana dengan beberapa kelebihan, seperti prosesnya lebih cepat, kondisinya lebih ringan dan menggunakan energi yang rendah sehingga teknik gelombang mikro menghindari sintesis multi-step [9]. Teknik gelombang mikro dipilih karena teknik yang sederhana untuk menghasilkan C-dots. Beberapa penelitian sebelumnya telah banyak menunjukkan bahwa teknik gelombang mikro mudah untuk mensintesis C-dots dengan berbagai sumber, seperti gliserol [10], asam sitrat [11], asam askorbat [12], gula putih pasir [13], arginine [9], kulit jeruk [14], jahe dan lengkuas [15], ampas anggur, [16]. Namun, belum ada yang menggunakan daun bambu sebagai sumber karbon untuk pembuatan C-dots menggunakan teknik gelombang mikro berbasis sintesis hijau. Hal tersebut menjadi sesuatu yang baru dan menarik untuk diamati dalam perkembangan sintesis C-dots.

\section{Bahan dan Metode}

Sintesis C-dots dilakukan menggunakan teknik gelombang mikro berbasis sintesis hijau. Air digunakan sebagai pelarut non-kimia dalam proses sintesis hijau. Sintesis hijau dilakukan menggunakan gelombang mikro 450 watt dengan diatur variasi konsentrasi larutan prekusor C-dots untuk mengetahui pengaruhnya terhadap sifat fisik dan optiknya. Skema sintesis hijau C-dots dapat dilihat pada Gambar 1. Sifat optik C-dots dikarakterisasi menggunakan spektrofotometer UV-Vis dan spektrofluorometer dengan sumber eksitasi $405 \mathrm{~nm}$. Data absorbansi dan C -dots yang diperoleh selanjutnya di-plot menggunakan software open acces gnuplot 4.6.

\subsection{Alat dan Bahan}

Alat yang digunakan dalam penelitian ini, yaitu blender, oven, kertas saring, gelas beker, erlenmeyer, corong, botol reagen, dan spektrofotometer UV-Vis dan spektrofluorometer. Sedangkan, bahan yang digunakan, yaitu daun bambu dan air. 


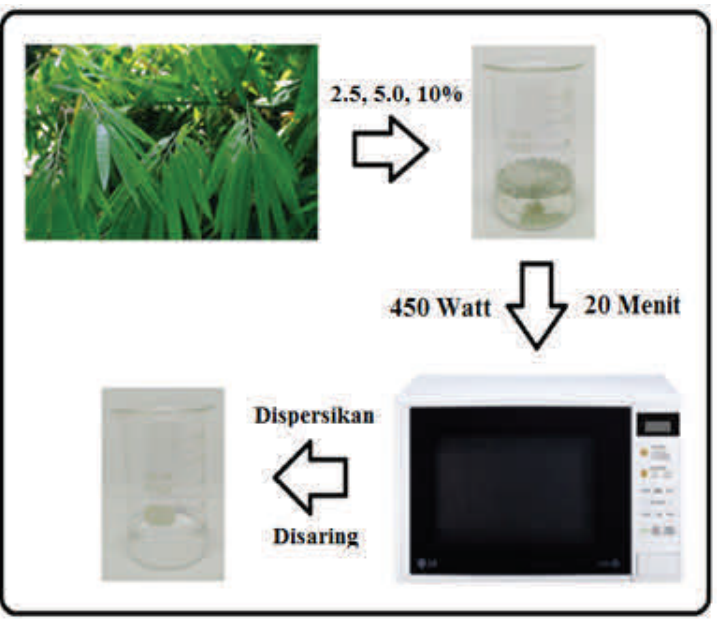

Gambar 1. Skema sintesis hijau C-dots menggunakan daun bamboo

\subsection{Sintesis Hijau C-dots}

Daun bambu dicuci menggunakan air dan dimasukan ke dalam oven pada temperatur 100C selama 1 jam untuk menghilangkan kadar air. Daun bambu di-blender hingga halus menjadi serbuk. Pembuatan larutan prekursor divariasikan konsentrasinya 2.5, 5.0 dan 10\% dalam $20 \mathrm{ml}$ air. Larutan prekursor masing-masing dimasukan ke dalam microwave 450 watt selama 20 menit sehingga larutan menjadi kering. Sampel didispersikan menggunakan 20 $\mathrm{ml}$ air dan diaduk menggunakan magnetic stirrer dengan kecepatan 200 rpm selama 20 menit. Sampel disaring menggunakan kertas saring ukuran 425 m sehingga diperoleh koloid C-dots transparan. Koloid C-dots dilakukan pengujian secara visual menggunakan laser UV $405 \mathrm{~nm}$ untuk mengetahui perilaku respons optiknya.
2.3 Karakterisasi C-dots

Koloid C-dots dikarakterisasi spektrum fotoluminesens (FL) menggunakan spektrofluorometer merk Ocean Optics $^{T M} 4000$ menggunakan picosecond diode laser pada panjang gelombang $405 \mathrm{~nm}$ sebagai sumber eksitasi. Pengaturan (setup) optik hibrida FL dapat dilihat pada Gambar 2. Sebuah laser memancarkan cahaya Pico-second pada panjang gelombang $405 \mathrm{~nm}$ yang digunakan sebagai energi yang diserap (eksitasi) C-dots. Emisi C-dots dikumpulkan (difokuskan) dan diarahkan ke detektor spektrofluorometer.

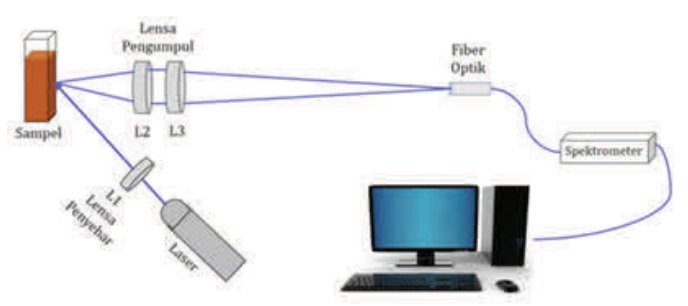

Gambar 2. Pengaturan pengukuran optik [17]

Sedangkan, karakterisasi spektrum absorbansi C-dots menggunakan spektrofotometer UV-Vis merk Ocean Optics $^{T M} 2000$ dengan lampu Halogen sebagai sumber cahaya. Pengaturan (setup) optik absorbasi dapat dilihat pada Gambar 3. Data yang diperoleh ditampilkan pada spectra suite software. 


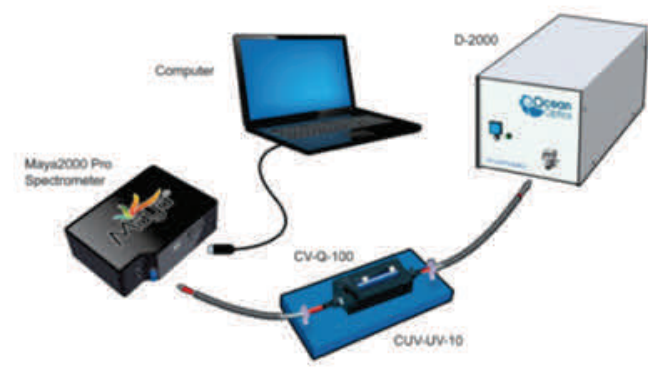

Gambar 3. Pengaturan pengukuran optik absorbansi

\section{Hasil dan Pembahasan}

C-dots yang diperoleh dari teknik microwave menghasilkan sifat fisik koloid C-dots yang dapat dilihat pada Gambar 4. Sifat fisik C-dots di bawah cahaya tampak menunjukkan warna yang transparan, sedangkan di bawah cahaya laser UV $405 \mathrm{~nm}$ menunjukkan warna hijau sebagai emisi dari C-dots. Peningkatan konsentrasi C-dots tidak merubah sifat fisik C-dots secara signifikan.

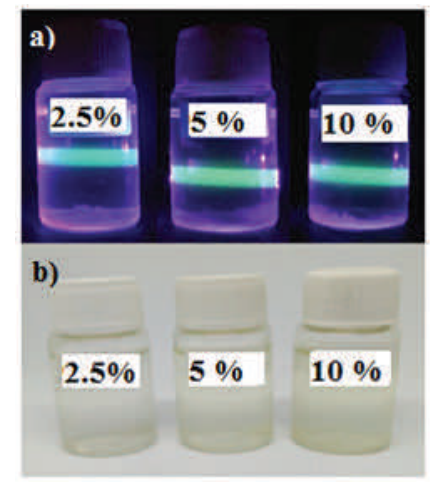

Gambar 4. Sifat fisik koloid C-dots; a) disinari laser UV $405 \mathrm{~nm}$; b) di bawah cahaya tampak

C-dots selanjutnya dikarakterisasi sifat optiknya, seperti spektrum absorbansi dan spektrum fotoluminesens (FL) berupa spektrum emisi menggunakan spektrofotometer UV-Vis dan spektrofluorometer. Sifat optik dilakukan untuk mengetahui puncak spektrum intensitas absorbansi dan fotoluminesens secara berturut-turut yang dapat dilihat pada Gambar 5. dan Gambar 7.

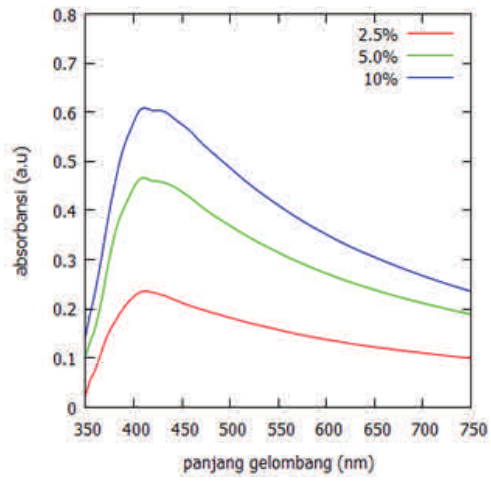

Gambar 5. Kurva absorbansi C-dots dengan variasi konsentrasi prekursor.

Nilai absorbansi C-dots sangat dipengaruhi oleh konsentrasi prekursor saat sintesis. Hubungan intensitas puncak absorbansi dan panjang gelombang pada setiap sampel C-dots dapat dilihat pada Gambar 6. Hal ini menunjukkan bahwa, semakin banyaknya C-dots yang terbentuk seiring meningkatnya konsentrasi prekursor. Spektrum absorbasni pada konsentrasi 2.5\%, $5 \%$, dan $10 \%$ secara berturut-turut terdapat puncak pada panjang gelombang $407.83 \mathrm{~nm}$, 408.65 dan $411.71 \mathrm{~nm}$ menunjukkan keadaan transisi $\mathrm{n}-\pi^{*}$ dari struktur ikatan aromatik $\mathrm{C}=\mathrm{O}$ yang berasal dari permukaan $\mathrm{C}$-dots $[18$ -20]. Spektrum ini cenderung stabil karena pergeseran puncaknya yang kecil atau tidak signifikan [21]. 


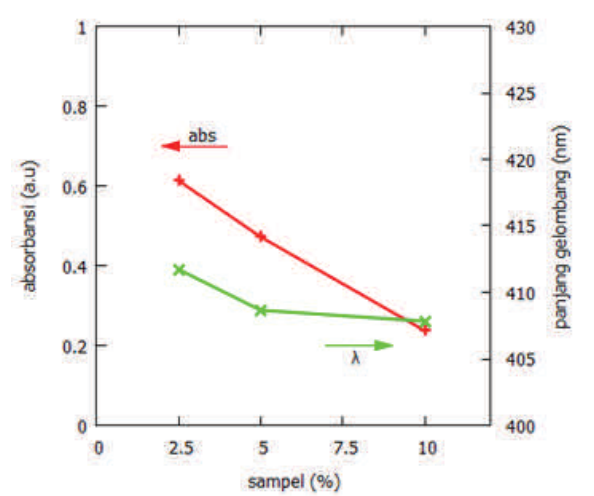

Gambar 6. Kurva hubungan puncak absorbansi dan panjang gelombang C-dots

Terjadi karena adanya pembangkitan elektron yang mendapatkan energi dari sinar UV pada panjang gelombang 405 $\mathrm{nm}$ yang digunakan sebagai sumber eksitasi. Energi ini akan menyebabkan terjadinya fenomena eksitasi dan deeksitasi berupa loncatan elektron dari pita valensi ke pita konduksi pada keadaan tertentu elektron selanjutnya akan kembali mengisi kekosongan yang semula ditinggalkan, hal inilah yang selanjutnya menyebabkan pelepasan energi berupa emisi.

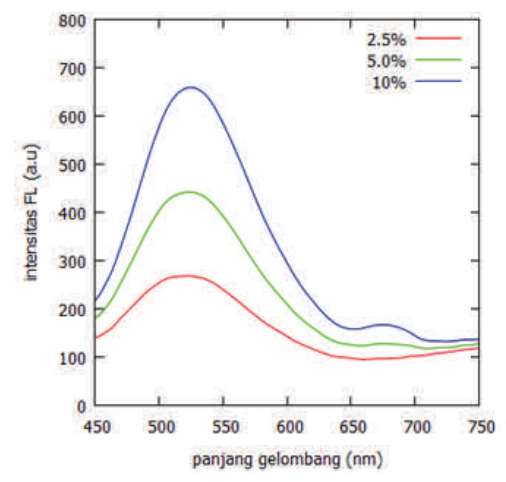

Gambar 7. Kurva C-dots dengan variasi konsentrasi prekursor
Intensitas fluoresensi C-dots sangat dipengaruhi oleh konsentrasi prekursor saat sintesis. Hal ini menunjukkan bahwa, peningkatan konsentrasi prekursor akan meningkatkan banyaknya C-dots yang terbentuk. Fluoresensi C-dots tidak disebabkan oleh transisi energi gap tetapi keadaan transisi permukaan pada energi gap [22]. Puncak FL mengalami pergeseran merah secara berturut-turut dengan meningkatnya konsentrasi prekursor dari $2.5 \%$, 5.0\% dan $10 \%$ adalah $521.39 \mathrm{~nm}$, $524.67 \mathrm{~nm}$ dan $526.72 \mathrm{~nm}$. Pergeseran merah yang diamati dalam puncak FL dianggap berasal dari gugus karboksil dan derajat oksidasi pada struktur permukaan dan bukan dari ukuran partikel, berarti sifat FL C-dots ini tidak seperti pada semikonduktor quantum dots. Oksidasi permukaan berfungsi sebagai pusat penangkapan eksiton sehingga menghasilkan fluoresensi yang berhubungan dengan keadaan permukaan. Tingkat oksidasi yang lebih tinggi pada permukaan C-dots menyiratkan lebih banyak cacat permukaan [23].

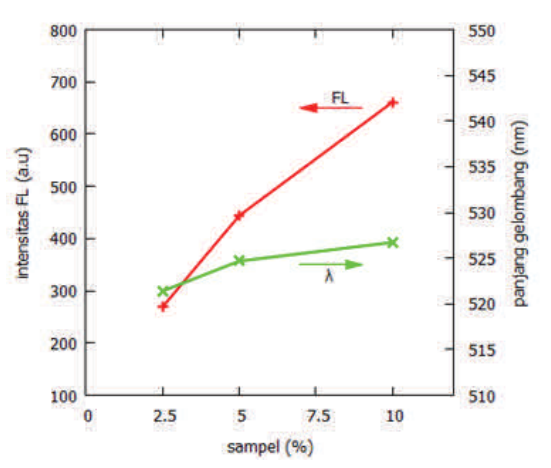

Gambar 8. Kurva hubungan puncak intensitas FL dan panjang gelombang C-dots 
Quantum confinement effect pada C-dots dapat dianalisis melalui pergeseran energi dari keadaan eksitasi dan emisi yang dapat dilihat pada Gambar 9. Pergeseran energi Cdots dengan variasi konsentrasi prekursor dari $2.5 \%, 5.0 \%$ dan $10 \%$ secara berturut-turut adalah $0.633571 \mathrm{eV}, 0.670992 \mathrm{eV}$ dan $0.686291 \mathrm{eV}$. Pergeseran energi ini disebabkan oleh interaksi elektron-hole sehingga terjadi pemisahan antara level energi dari pita valensi dan konduksi. Pergeran energi ini biasa dikenal dengan pergeseran Stokes.

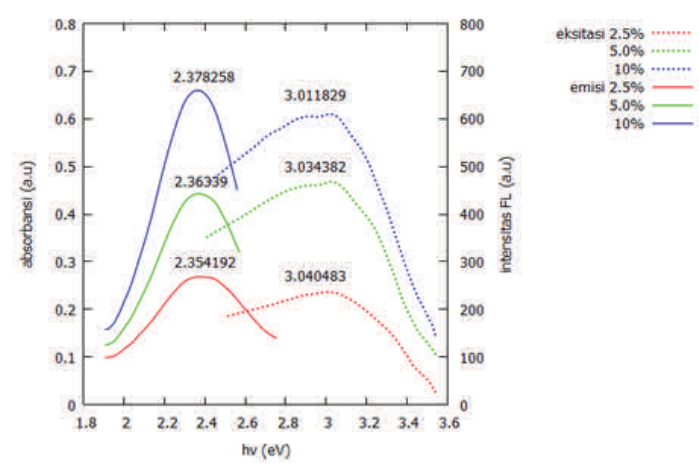

Gambar 9. Kurva pergeseran energi dari keadaan eksitasi dan emisi Cdots dengan variasi konsentrasi prekursor

Pergeseran Stokes pada C-dots meningkat seiring dengan meningkatnya konsentrasi prekursor, namun tidak signifikan. Hal ini menunjukkan bahwa waktu relaksasi dari inti sebelum melakukan emisi sangat stabil dalam larutan berair dengan intensitas yang dapat diatur berdasarkan konsentrasi prekursor Cdots. Hasil ini memberikan potensi C-dots dari daun bambu dalam larutan berair untuk diaplikasikan sebagai bioimaging seluler in vivo dan in vitro dan biosensing ion logam dan garam.

\section{Simpulan}

Sintesis hijau C-dots berhasil dilakukan menggunakan daun bambu sebagai sumber karbon dan air sebagai pelarutnya. C-dots yang diperoleh memiliki fluorensi berupa emisi yang baik tanpa pasivasif eksternal atau fungsionalisasi permukaan. Konsentrasi prekursor mempengaruhi intensitas eksitasi dan emisi, namun pergeseran Stokes pada C-dots memiliki kestabilan yang sangat baik dalam larutan berair sehingga berpotensi untuk diaplikasikan sebagai bioimaging seluler in vivo dan in vitro dan biosensing ion logam dan garam.

\section{Referensi}

1. Gonçalves, H., \& da Silva, J. C. E. (2010). Fluorescent carbon dots capped with PEG 200 and mercaptosuccinic acid. Journal of fluorescence, 20(5), 1023-1028.

2. Hassan, M., Gomes, V. G., Dehghani, A., \& Ardekani, S. M. (2018). Engineering carbon quantum dots for photomediated theranostics. Nano Research, 11 (1), 1-41.

3. Jaleel, J. A., \& Pramod, K. (2018). Artful and multifaceted applications of carbon dot in biomedicine. Journal of Controlled Release, 269, 302-321. 
4. Baker, S. N., \& Baker, G. A. (2010). Luminescent carbon nanodots: emergent nanolights. Angewandte Chemie International Edition,49(38), 67266744.

5. Goryacheva, I. Y., Sapelkin, A. V., \& Sukhorukov, G. B. (2017). Carbon nanodots: mechanisms of photoluminescence and principles of application. TrAC Trends in Analytical Chemistry, 90, 27-37.

6. Liu, Y., Zhao, Y., \& Zhang, Y. (2014). One-step green synthesized fluorescent carbon nanodots from bamboo leaves for copper (II) ion detection. Sensors and Actuators B: Chemical, 196, 647652.

7. Su, L. X., Ma, X. L., Zhao, K. K., Shen, C. L., Lou, Q., Yin, D. M., \& Shan, C. X. (2018). Carbon Nanodots for Enhancing the Stress Resistance of Peanut Plants. ACS Omega,3(12), 17770-17777.

8. Wang, R., Lu, K. Q., Tang, Z. R., \& Xu, Y. J. (2017). Recent progress in carbon quantum dots: synthesis, properties and applications in photocatalysis. Journal of Materials Chemistry A, 5(8), 37173734.

9. Arcudi, F., Đorđević, L., \& Prato, M. (2016). Synthesis, Separation, and Characterization of Small and Highly Fluorescent Nitrogen-Doped Carbon NanoDots. Angewandte Chemie International Edition, 55(6), 2107-2112.
10. Wang, X., Qu, K., Xu, B., Ren, J., \& Qu, X. (2011). Microwave assisted onestep green synthesis of cell-permeable multicolor photoluminescent carbon dots without surface passivation reagents. Journal of Materials Chemistry, 21(8), 2445-2450.

11. Wright, P. C., Qin, H., Choi, M. M., Chiu, N. H., \& Jia, Z. (2014). Carbon nanodots interference with lactate dehydrogenase assay in human monocyte THP-1 cells. SpringerPlus, 3 (1), 615 .

12. Sugiarti, S., \& Darmawan, N. (2015). Synthesis of Fluorescence Carbon Nanoparticles from Ascorbic Acid. Indonesian Journal of Chemistry, 15(2), 141-145.

13. Herbani, Y., \& Suliyanti, M. M. (2018). Concentration effect on optical properties of carbon dots at room temperature. Journal of Luminescence, 198, 215-219.

14. Fatimah, S., Isnaeni, I., \& Tahir, D. (2018). Assisted Surface-state Recombination of Orange-peel Carbon Nanodots in Various Matrices. Makara Journal of Science, 29-34.

15. Rahmawati, I., Intan, R., \& Zakaria, M. (2018, March). Photoluminescence study of carbon dots from ginger and galangal herbs using microwave technique. In Journal of Physics: Conference Series (Vol. 985, No. 1, p. 012004). IOP Publishing. 
16. Varisco, M., Zufferey, D., Ruggi, A., Zhang, Y., Erni, R., \& Mamula, O. (2017). Synthesis of hydrophilic and hydrophobic carbon quantum dots from waste of wine fermentation. Royal Society open science, 4(12), 170900.

17. Fatimah, S., Isnaeni, I., \& Tahir, D. (2017). Sintesis dan Karakterisasi Fotoluminisens Carbon Dots Berbahan Dasar Organik dan Limbah Organik. POSITRON, 7(2), 37-41.

18. Li, Q., Zhou, M., Yang, M., Yang, Q., Zhang, Z., \& Shi, J. (2018). Induction of long-lived room temperature phosphorescence of carbon dots by water in hydrogen-bonded matrices. Nature communications, 9 (1), 734.

19. Han, S., Chang, T., Zhao, H., Du, H., Liu, S., Wu, B., \& Qin, S. (2017). Cultivating Fluorescent Flowers with Highly Luminescent Carbon Dots Fabricated by a Double Passivation Method.Nanomaterials, 7(7), 176.

20. Jhonsi, M. A., \& Kathiravan, A. (2017). Photoinduced interaction of arylamine dye with carbon quantum dots ensued from Centella asiatica. Journal of Luminescence, 192, 321 $-327$.

21. Li, X., Zhang, S., Kulinich, S. A., Liu, Y., \& Zeng, H. (2014). Engineering surface states of carbon dots to achieve controllable luminescence for solid- luminescent composites and sensitive Be $2+$ detection. Scientific reports, 4 , 4976.

22. Yoshinaga, T., Iso, Y., \& Isobe, T. (2018). Particulate, structural, and optical properties of D-glucose-derived carbon dots synthesized by microwaveassisted hydrothermal treatment. ECS Journal of Solid State Science and Technology, 7(1), R3034-R3039.

23. Ding, H., Yu, S. B., Wei, J. S., \& Xiong, H. M. (2015). Full-color light-emitting carbon dots with a surface-statecontrolled luminescence mechanism. ACS nano, 10(1), 484-491. 